\title{
Preparative Purification of Delphinidin 3-0-sambubioside from Roselle (Hibiscus sabdariffa L.) Petals by fast Centrifugation Partition Chromatography
}

Tanoh Hilaire Kouakou ${ }^{\mathrm{a}, \mathrm{b}^{*}}$, Laurent Kouakou Kouakou ${ }^{\mathrm{b}}$, Alain Decendit ${ }^{\mathrm{a}}$, Alain Badoc ${ }^{\mathrm{a}}$, Gregory DA-Costa ${ }^{a}$, Jean-Michel Mérillon ${ }^{a}$, Pierre Waffo Téguo ${ }^{a}$

${ }^{a}$ Université de Bordeaux2, ISVV, Groupe d'Etude des Substances Végétales à Activité Biologique, EA 3675, F-33882 Villenave d'Ornon, France

alain.decendit@u-bordeaux2.fr ; jbtalence@free.fr ; gregory.dacosta@u-bordeaux2.fr ; jean-michel.merillon@u-bordeaux2.fr ; pierre.waffoteguo@u-bordeaux2.fr

${ }^{\mathrm{b}}$ Laboratoire de Biologie et d'Amélioration des Productions végétales, UFR Sciences de la Nature, Université Nangui Abrogoua, 02 BP 801 Abidjan 02, Côte d'Ivoire tanohilaire@yahoo.fr;kk_laurent@yahoo.fr

* Corresponding author: Tel:+225-20304200; Fax: +225-20378118; e-mail: tanohilaire@yahoo.fr

\begin{abstract}
Delphinidin 3-0-sambubioside, a Hibiscus anthocyanin, was isolated from MeOH/TFA dried flower of $H$. sabdariffa. Its purification on preparative scale was obtained by centrifugal partition chromatography (CPC) using the ternary biphasic solvent systems composed of ethyl acetate/1-butanol/water, acidified by $0.1 \%$ of TFA. Stationary phase was ethyl acetate/1-butanol/water $(5: 5: 90 ; \mathrm{v} / \mathrm{v})$. We tested 4 mobile phases and found that the system acetate/1-butanol/water $(40: 46: 14 ; \mathrm{v} / \mathrm{v})$ was the best to separate anthocyanin mentioned above. This support-free liquid-liquid chromatographic procedure made it possible to isolate delphinidin 3-0-sambubioside from flower of $H$. sabdariffa. The antiamyloidogenic activity of the isolated stilbenes was evaluated versus $\beta$-amyloid fibrils. Delphinidin $3-0$-sambubioside was found to be active with $67 \%$ inhibition at $10 \mu \mathrm{M}$.
\end{abstract}

Keywords: Centrifugal partition chromatography; Hibiscus sabdariffa L; anthocyanins; delphinidin 3-sambubioside.

Abbreviations: FCPC: Fast Centrifugal Partition Chromatography; HPLC: high-performance liquid chromatography; DAD: diode array detection; TFA: trifluoroacetic acid; TLC: thin-layer chromatography; ESI-MS: electrospray ionization mass spectrometer; NMR: nuclear magnetic resonance

\section{Council for Innovative Research}

Peer Review Research Publishing System

Journal: Journal of Advances in Chemistry

Vol. 6, No. 2

editor@cirworld.com

www.cirworld.com, member.cirworld.com 


\section{Introduction}

In recent times, focus on plant research has increased all over the world and a large body of evidence has collected to show immense potentials of medicinal plants used in various traditional systems. Various medicinal plants have been studied using modern scientific approaches. The results from these plants have revealed the potentials of medicinal plants in the area of pharmacology [1-2]. Hibiscus sabdariffa L., a member of the Malvaceae family, is an annual shrub that grows in regions where dry tropical weather prevails. It is known as roselle (English), l'oiselle (French), spanish (Jamaica), karkade (Arabic) and bissap (Wolof). In some countries, its shrubbery is used to decorative purposes, in others, the seeds and petals are used for human consumption. Nevertheless, in most cases it is cultivated with the purpose of using the calyxes to produce infusions that are consumed like tea [3] or petals to produce infusions that are used for sauces and jams or preparation of Bissap: infusion and syrup producing a red drink, drunk fresh and very sweet (sometimes prepared with mint) in West Africa. Also, the seeds are cooked and fermented into a meat substitute or condiment known as "Furundu" in Sudan [4] or "Dadawa baso" in Nigeria [5]. Nowadays, a great interest exists in the crop of Roselle due to the high antioxidant properties of the flowers, which have been extensively evaluated $[6,7]$. The flower extract have been used commonly as in folk medicines against hypertension, pyrexia, inflammation, diabetes, arthritis, liver disorders and obesity [8,9]. It is generally supposed that the active constituents contributing to these protective effects are anti-oxidant nutrients such as vitamin $\mathrm{E}, \beta$-carotene and anthocyanins [10].

The major constituents in Hibiscus extract are anthocyanins, which are natural water-soluble pigments belonging to the class of flavonoids $[11,12]$. They are responsible for the orange, pink, red, purple and blue colours of many flowers, fruits and leafs from many higher plants [12,13]. These secondary metabolites are glycosylated derivatives of polyhydroxylated and/or polymethoxylated 2-phenylbenzopyrilium (or flavylium) salts. Moreover, since a few decades, some attention is regained on anthocyanins owing to their interesting potential as health preserving substances [14-17]. Hibiscus anthocyanins have been reported to possess antioxidative effects, anticarcinogenic effects [18], inhibition effects on apoptosis [19,20], protective effect against the oxidative stress [21] and possess anti-inflammatory activity by blocking the production of various mediators such as prostaglandins [22]. Thus, the possibility that Hibiscus anthocyanins have antitumor effect needs to be considered. Anthocyanins also mediate physiological functions related to cancer suppression [23-27]. The growth inhibitory effects of anthocyanins in K-562 leukemia, and HCT-15 carcinoma cells are stronger than those of other phenolic components, such as flavonols and flavanones [28].

Bioavailability and metabolic fate studies combined with clinical trials require large amount of pure anthocyanins. Existing HPLC techniques are not suitable for large-scale purification of these polar, fragile and pH-sensitive polyphenols due to irreversible adsorptions often encountered on solid support. Centrifugal Partition Chromatography (CPC), a support-free liquid-liquid chromatographic technique, has appeared to be a powerful alternative for pure anthocyanin production. With a view to large-scale purification of such compounds, CPC which is known to provide high loading, low cost and high recovery rates, has been investigated [28].

The successful preparative purification of delphinidin 3-0-sambubioside (Figure 1) from the methanolic extract of the flower of $H$. sabdariffa by XAD-7 column chromatography and CPC is described in this paper.

\section{Experimental}

\section{1. $\quad$ CPC apparatus}

The laboratory CPC is a FCPC200 ${ }^{\circledR}$ apparatus provided by Kromaton Technologies (Angers, France) that is fitted with a rotor made of 20 circular partition disks (1320 partition cells: $0.130 \mathrm{~mL}$ per cell; total column capacity of $204 \mathrm{~mL}$; dead volume: $32.3 \mathrm{~mL}$ ). Distance from the centre of the rotor to the centre of each cell is $105 \mathrm{~mm}$. Rotation speed can be adjusted from 0 to $2000 \mathrm{rpm}$, thus producing a centrifugal force field in the partition cell of nearly $1200 \mathrm{~m} . \mathrm{s}^{-2}$ at $1100 \mathrm{rpm}$ and $4200 \mathrm{~m} . \mathrm{s}^{-2}$ at $2000 \mathrm{rpm}$.

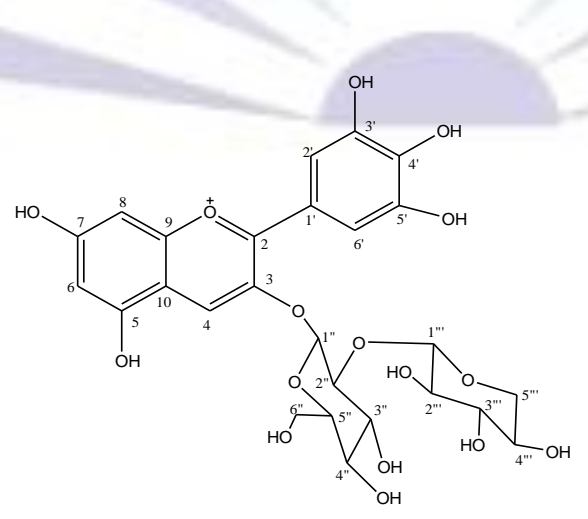

Fig. 1. Chemical structure of delphinidin 3-O-sambubioside

The solvents were pumped by a Gilson 321-H1 2-way binary high-pressure gradient pump. The samples were introduced into the CPC column via a high pressure injection valve (3725(i)038 Rheodyne ) equipped with a $10 \mathrm{~mL}$ sample loop. The 
effluent was monitored with an UV-Lambda 1010 detector equipped with a preparative flow cell. Fractions were collected by a Gilson FC 204 fraction collector. The experiments were conducted at room temperature.

\subsection{Reagents}

All organic solvents were HPLC grade and purchased from Scharlau (Sentmenat, Spain). Water was bi-distilled.

\subsection{Preparation of the crude extract of anthocyanins}

Dried and finely powdered petals of $H$. sabdariffa L. cv. LP1 $(100 \mathrm{~g})$ were extracted with 2 times $1 \mathrm{~L}$ of MeOH with $0.1 \%$ $(\mathrm{v} / \mathrm{v})$ TFA at the room temperature under agitation during 2 hours. After filtration, the TFA methanolic solution was evaporated to dryness at $30{ }^{\circ} \mathrm{C}$ to yield crude pigment $(52 \mathrm{~g})$. The crude extract was redissolved in $0.1 \%$ aq. TFA and applied on amberlite XAD-7 CC. The column was washed with $0.1 \%$ aq. TFA followed by elution with $\mathrm{MeOH}$ with $0.1 \%$ (v/v) TFA and gave $4 \mathrm{~g}$ of a prepurified extract which was used without further purification for CPC experiments.

\subsection{Preparation of the two -phase solvent}

The ternary solvent systems were prepared by mixing EtOAc, 1-butanol and water in the convenient proportion (5:5:90 $\mathrm{v} / \mathrm{v})$ for the stationary phase and $(40: 46: 14 \mathrm{v} / \mathrm{v})$ for the mobile phase. Each phase was acidified with $0.1 \%$ TFA.

\subsection{Separation procedure}

The rotor was entirely filled with the aqueous stationary phase in the ascending mode without rotating. After injection of the $2 \mathrm{~g}$ of prepurified anthocyanins extract initially dissolved in $8 \mathrm{ml}$ of the organic/aqueous phase mixture (1:1), the organic mobile phase was pumped into the column in ascending mode at a flow-rate of $3 \mathrm{~mL} / \mathrm{min}$. Then, the rotation speed was increased to $1000 \mathrm{rpm}$. Fractions of $9 \mathrm{ml}$ were collected every 3 minutes. The back pressure was 25 bars. The stationary phase retention at the end of the separation represented $75 \%$ of the column volume. The content of the outgoing organic phase was monitored by online UV absorbance measurement at $\square=280 \mathrm{~nm}$.

\subsection{HPLC analysis of anthocyanins}

HPLC analysis was performed on VARIAN apparatus equipped with an autosampler model 410, a Prostar Pump model 210, a Prostar diode array detector model 335, and running on Star software. A $\mathrm{C}_{18}$ reversed phase column (Prontosil, $250 \times 4.0 \mathrm{~mm}, 5 \mu \mathrm{m}$, Bischoff) was used for analysis. The mobile phase was composed of two solvents: A, $0.1 \%$ TFA in $\mathrm{H}_{2} \mathrm{O}$ and $\mathrm{B}, 0.1 \%$ TFA in MeCN. The sample was dissolved in $0.1 \%$ TFA in $\mathrm{MeOH} / \mathrm{H}_{2} \mathrm{O}(1 / 1)$ and filtered through a $0.45 \square \mathrm{m}$ Millipore filter. The elution program at $1 \mathrm{ml} / \mathrm{min}$ was as follows: 10 to $35 \% \mathrm{~B}(0-35 \mathrm{~min}), 35$ to $100 \% \mathrm{~B}$ (35-40 $\mathrm{min}), 100 \%$ B (40-50 min). $20 \mu$ of each sample were directly injected and chromatograms were monitored at 280 and $521 \mathrm{~nm}$.

\subsection{TLC analysis}

All the fractions were checked by TLC cellulose plates (Merck) and developed with 1-butanol-acetic acid-water (4:1:5) upper phase.

\section{Results and Discussion}

As shown in Figure 2A, the HPLC-diode array detection chromatogram of the prepurified extract obtained from flowers of $H$. sabdariffa allows to see the main anthocyanin as indicated by UV-Visible spectrum.

In order to achieve successful separation of these anthocyanins in the extract using centrifugal partition chromatography (CPC), a biphasic solvent system was first selected on the basis of partition coefficient value of each compound. 


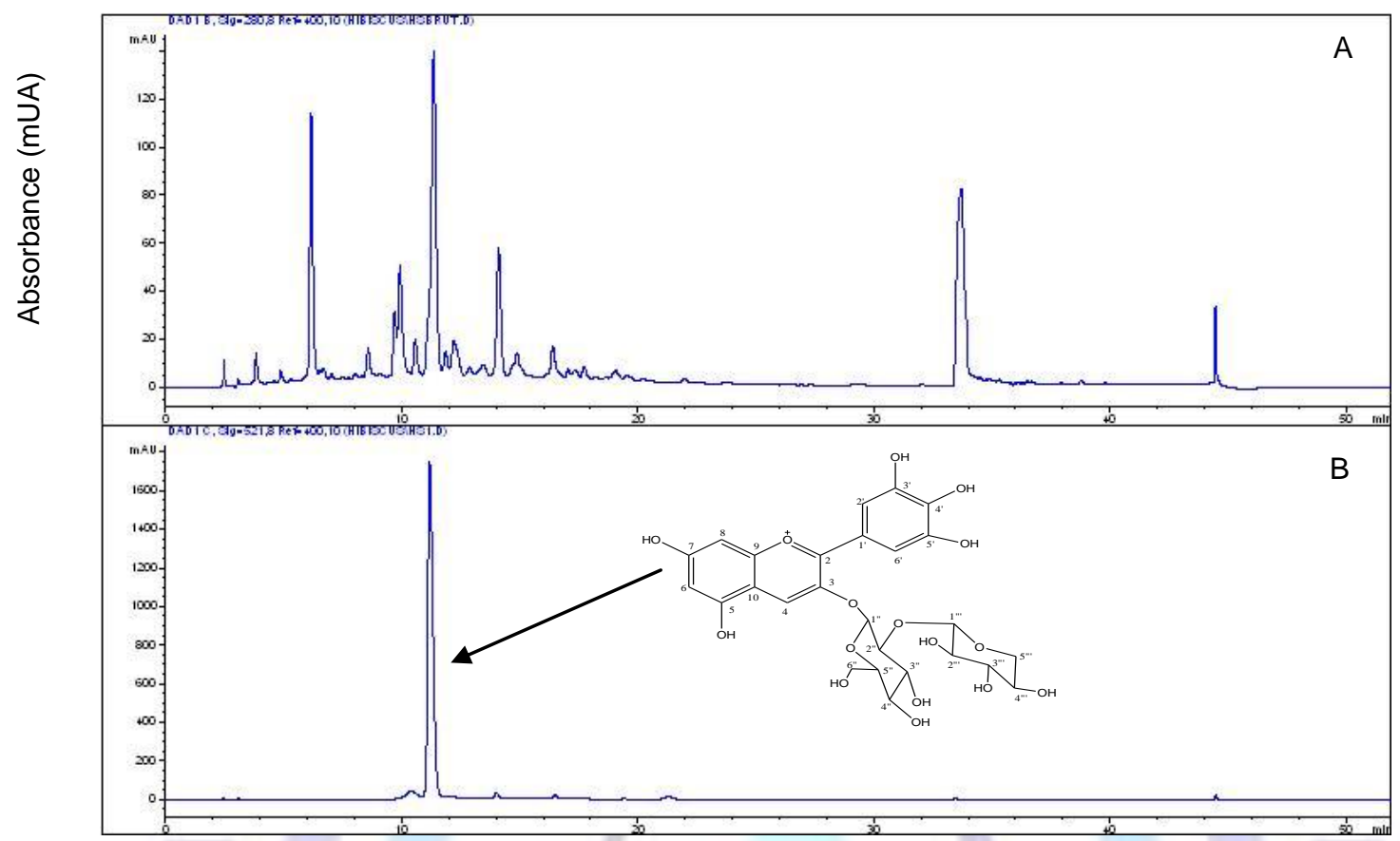

Retention time (min)

Fig. 2: HPLC chromatogram of A: prepurified anthocyanin roselle extract and B: delphinidin 3-O-sambubioside. Experimental conditions: mobile phase, two solvents: $A, 0.1 \%$ TFA in $\mathrm{H}_{2} \mathrm{O}$ and $\mathrm{B}, 0.1 \%$ TFA in MeCN. The sample was dissolved in $0.1 \%$ TFA in $\mathrm{MeOH} / \mathrm{H}_{2} \mathrm{O}(1 / 1)$ and filtered through a $0.45 \mathrm{~mm}$ Millipore filter. Elution program at $1 \mathrm{~mL} / \mathrm{min}$ was as follows: 10 to $35 \% \mathrm{~B}(0-35 \mathrm{~min}), 35$ to $100 \% \mathrm{~B}(35-40 \mathrm{~min})$, $100 \%$ B (40-50 min).

We have tested four mobile phases. Their respective compositions (EtOAc-1-butanol-water) were (96:0:4), (77:15:8), $(60: 30: 10)$, and (40:46:14) and the latter gave the best results. The stationary aqueous phase EtOAc-1-butanol-water (5:5:90) was prepared separately.

Therefore, the preparative CPC separation of the prepurified anthocyanin extract was performed in EtOAc-1butanol-water (40:46:14) as mobile phase and EtOAc-1-butanol-water (5:5:90) as stationary phase led to 124 fractions (Figure 3). Fractions (63-80) seemed to contain only one compound, an anthocyanin, according to the TLC analysis. Hence, the fractions were pooled together, evaporated to dryness (120 mg) analysed by HPLC-DAD (Figure 2B).

The structure elucidation of delphinidin 3-O-sambubioside (Fr. 63-80) was confirmed by examining ESI-MS, ESIMS/MS, and NMR 1D and 2D spectra as follows:

ESI-MS m/z: 597 [M] ${ }^{+} ;{ }^{1} \mathrm{H}-\mathrm{NMR}\left(600 \mathrm{MHz}, \mathrm{CD}_{3} \mathrm{OD} / \mathrm{TFA}\right) \delta(\mathrm{ppm}): 8.90(1 \mathrm{H}, \mathrm{s}, \mathrm{H}-4), 7.77\left(2 \mathrm{H}, \mathrm{s}, \mathrm{H}-2^{\prime}, \mathrm{H}-6{ }^{\prime}\right), 6.87(1 \mathrm{H}, \mathrm{d}$, $J=1.3 \mathrm{~Hz}, \mathrm{H}-6), 6.66(1 \mathrm{H}, \mathrm{d}, J=1.3 \mathrm{~Hz}, \mathrm{H}-8), 5.48\left(1 \mathrm{H}, \mathrm{d}, J=7.6 \mathrm{~Hz}, \mathrm{H}-1^{\prime \prime}\right), 4.7\left(1 \mathrm{H}, \mathrm{d}, J=7.2 \mathrm{~Hz}, \mathrm{H}-1^{\prime \prime \prime}\right), 4.08(1 \mathrm{H}, \mathrm{dd}, J=12.2$ and $\left.2.2 \mathrm{~Hz}, \mathrm{H}-6 \mathrm{~b}^{\prime \prime}\right), 4.00\left(1 \mathrm{H}, \mathrm{dd}, \mathrm{J}=9\right.$ and $\left.7.6 \mathrm{~Hz}, \mathrm{H}-2^{\prime \prime}\right), 3.78\left(1 \mathrm{H}, \mathrm{t}, \mathrm{J}=9 \mathrm{~Hz}, \mathrm{H}-3^{\prime \prime}\right), 3.74(1 \mathrm{H}, \mathrm{dd}, \mathrm{J}=12.2 \mathrm{and} 5.8 \mathrm{~Hz}, \mathrm{H}-$ $\left.6 a^{\prime \prime}\right), 3.60\left(1 \mathrm{H}, \mathrm{dd}, \mathrm{J}=11.5\right.$ and $\left.5.4 \mathrm{~Hz}, \mathrm{H}-5 \mathrm{~b}^{\prime \prime \prime}\right), 3.55\left(1 \mathrm{H}, \mathrm{m}, \mathrm{H}-5^{\prime \prime}\right), 3.52\left(1 \mathrm{H}, \mathrm{t}, \mathrm{J}=9 \mathrm{~Hz}, \mathrm{H}-4^{\prime \prime}\right), 3.37\left(1 \mathrm{H}, \mathrm{m}, \mathrm{H}-4^{\prime \prime \prime}\right), 3.33$ $\left(1 \mathrm{H}, \mathrm{t}, \mathrm{J}=9 \mathrm{~Hz}, \mathrm{H}-3^{\prime \prime \prime}\right) 3.18\left(1 \mathrm{H}, \mathrm{dd}, \mathrm{J}=9\right.$ and $\left.7.7 \mathrm{~Hz}, \mathrm{H}-2^{\prime \prime \prime}\right)$, 


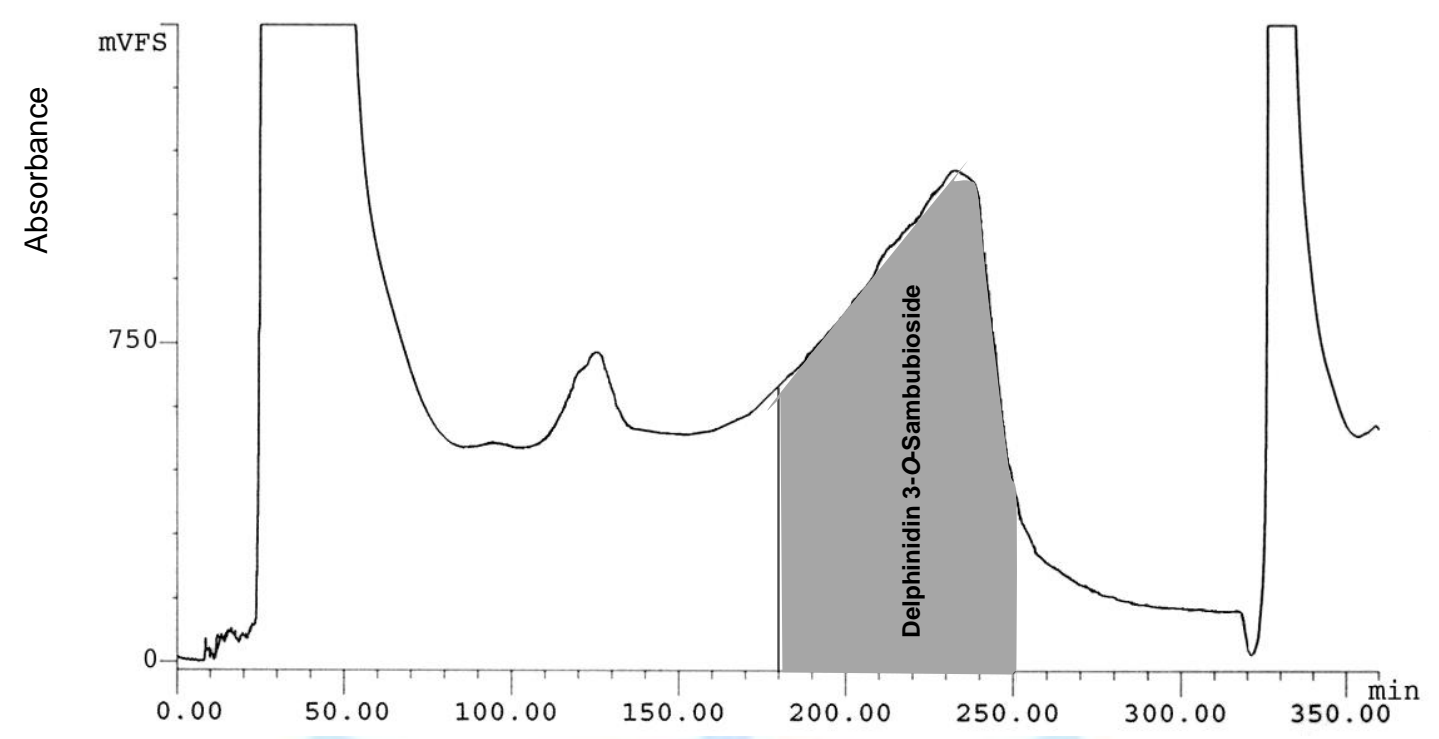

Retention time (min)

Fig. 3. Elution profile of prepurified anthocyanins extract from roselle in FCPC 200 of $2 \mathbf{g}$. The flow-rate was $3 \mathrm{~mL} / \mathrm{min}$ at $1000 \mathrm{rpm}$ and fractions were collected every $3 \mathrm{~min}$.

$2.98\left(1 \mathrm{H}\right.$, dd, $J=11.5$ and $\left.\left.10.4 \mathrm{~Hz}, \mathrm{H}-5 a^{\prime \prime \prime}\right) .{ }^{13} \mathrm{C}-\mathrm{NMR}\left(125 \mathrm{MHz}, \mathrm{CD}_{3} \mathrm{OD} / \mathrm{TFA}\right) \delta \mathrm{ppm}\right): 168.0$ (C-7), 162.8 (C-2), 157.7 (C9), 156.1 (C-5), 146.2 (C-3', C-5'), 144.1 (C-3), 143.3 (C-4'), 134.1 (C-4), $118.6\left(\mathrm{C}-1^{\prime}\right), 111.6(\mathrm{C}-10), 111.4\left(\mathrm{C}-2^{\prime}, \mathrm{C}^{\prime} \mathrm{6}^{\prime}\right)$, 104.7 (C-1"'), 100.3 (C-1"), 93.6 (C-6), 81.2 (C-2"), 77.3 (C-5"), 76.5 (C-3"), 76.3 (C-3"'), 74.4 (C-2"'), 69.4 (C-4"'), 69.3 (C$\left.4^{\prime \prime}\right), 65.6\left(\mathrm{C}-5^{\prime \prime \prime}\right), 60.8\left(\mathrm{C}-6^{\prime \prime}\right)$. The results were similar to those in the literature [29].

This CPC method, a very versatile separation technique which does not require a solid stationary phase, seems very suitable for obtaining pure anthocyanin using a crude anthocyanin extract. The most salient results here are the possibility to isolate directly in one step pure delphinidin 3-O-sambubioside $(120 \mathrm{mg})$ with greater than $90 \%$ from $2 \mathrm{~g}$ of prepurified extract in $3 \mathrm{~h}$. It has been shown that gram quantities of pure anthocyanins can easily be obtained in excellent yields by CPC. Our result also suggest that delphinidin 3-O-sambubioside a main constituent of roselle, is attractive new candidate for the protecting against dysfunction of brain cells in vivo in Alzheimer's disease by inhibiting the aggregation of $\mathrm{A} \beta$.

\section{Acknowledgements}

This study was supported by GESVAB (Groupe d'Etude des Substances Végétales à Activité Biologique), University Bordeaux 2.

\section{References}

1. Fatehi, M., Rashidabady, T., and Fatehi-Hassanabad, Z. 2003. Effects of Crocus stivus petals extract on rat blood pressure and on responses induced by electrical field stimulation in the rat isolated vas deferens and guinea-pig ileum. J. Ethnopharmacol. 84, 199-203.

2. Somova, L. I., Shode, F. O., Ramnanan, P., and Nadar, A. 2003. Antihypertensive, antiatherosclerotic and antioxidant activity of triterpenoids isolated from Olea europaea, subspecies africana leaves. J. Ethnopharmacol. 84 (2-3), 299305.

3. Domınguez-Lopez, A., Remondetto, G. E., and Navarro-Galindo, S. 2008. Thermal kinetics degradation of anthocyanins in a Roselle (Hibiscus sabdariffa L. cv. 'Criollo') infusion. Inter. J. Food Sci. Technol. 43, 322-325.

4. Yagoub, A. E. A., Mohamed, B. E., Ahmed, A. H. R., and El Tinay, A. H. 2004. Study on Furundu, a traditional sudanese fermented Roselle (Hibiscus sabdariffa L.) seed: Effect on in vitro protein digestibility, chemical composition, and functional properties of the total proteins. J. Agric. Food Chem. 52 (20), 6143-6150.

5. Dashak, D. A., Dawang, M. L., and Lucas, N. B. 2001. An assessment of the proximate chemical composition of locally produced spices known as dadawa basso and dadawa kalwa from three markets in Plateau State of Niger. Food Chem. 75 (2), 231-235.

6. Tsai, P. J., and Huang, H. P. 2004. Effect of polymerisation on the antioxidant capacity of anthocyanins in Roselle. Food Res. Inter. 37, 313-318. 
7. Prenesti, E., Berto, S., Daniele, P. G., and Toso, S. 2007. Antioxidant power quantification of decoction and cold infusions of Hibiscus sabdariffa flowers. Food Chem. 100 (2), 433-438.

8. Tseng, T. H., Kao, T. W., Chu, C. Y., Chou, F. P., Lin, W. L., and Wang, C. J. 2000. Induction of apoptosis by hibiscus protocatechuic acid in human leukemia cells via reduction of retinoblastoma (RB) phosphorylation and Bcl-2 expression. Biochem. Pharmacol. 60, 307-315.

9. Prior, R. L., and Wu, X. 2006. Anthocyanins: structural characteristics that result in unique metabolic patterns and biological activities. Free Radic. Res. 40 (10), 1014-1028.

10. Ramirez-Tortosa, C., Andersen, O. M., Gardner, P. T., Morrice, P. C., Wood, S. G., Duthie, S. J., Collins, A. R., and Duthie, G. G. 2001. Anthocyanin-rich extract decreases indices of lipid peroxidation and DNA damage in vitamin Edepleted rats. Free Radic. Biol. Med. 31 (9), 1033-1037.

11. Smith, M. A. L., Marley, K. A., Seigler, D., Singletary K. W., and Meline, B. 2000. Bioactive Properties of Wild Blueberry Fruits. J. Food Sci. 65 (2), 352-356.

12. Harborne, J. B. 1994. Flavonoids and flower colour. In: Harborne JB (ed.) The Flavonoids, Advances in Flavonoid Research since 1986, pp. 565-588. London: Chapman and Hall.

13. Mazza, G., and Minianti, E. 1993. Anthocyanins in Fruits, Vegetables and Grains, CRC Press, Boca Raton, Ann Arbor, London,

14. Tsuda, T., Watanabe, M., Ohshima, K., Norinobu, S., Choi, S. W., Kawakishi, S., and Osawa, T. 1994. Antioxidative activity of the anthocyanin pigments cyanidin 3-O-B-D-glucoside and cyanidin. J. Agric. Food Chem. 42, $2407-2410$.

15. Kamei, H., Kojima, T., Hasegawa, M., Koide, T., Umeda, T., Yukawa, T., and Terabe, K. 1995. Suppression of tumorcell by anthocyanins in vitro. Cancer Invest. 13, 590-594.

16. Igarashi, K. 2000. Physiological functions of food component anthocyanins. Foods \& Food Ingredients J. Jpn 187, 1729.

17. Smith, M. A. L., Marley, K. A., Seigler, D., Singletary, K. W., and Meline, B. 2000. Bioactive Properties of Wild Blueberry Fruits. J. Food Sci. 65 (2), 352-356.

18. Wang, L. S., and Stoner, G. D. 2008. Anthocyanins and their role in cancer prevention. Cancer Lett. 269, $281-290$.

19. Chang, Y. C., Huang, H. P., Hsu, J. D., Yang, S. F., and Wang, C. J. 2005. Hibiscus anthocyanins rich extract-induced apoptotic cell death in human promyelocytic leukemia cell. Toxicol. Appl. Pharmacol. 205, 201-212.

20. Dumitrita, R., Zorita, S., Loredana, L., Adela, P., Andrea, B., and Carmen, S. 2012. Antioxidant activities of chokeberry extracts and the cytotoxic action of their anthocyanin fraction on heLa human cervical tumor cells. J. Med. Food 15(8): 700-706.

21. Wang, C. J., Wang, J. M., Lin, W. L., Chu, C. Y., Chou, F. P., and Tseng, T.H., 2000. Protective effect of Hibiscus anthocyanins against tert-butyl hydroperoxide-induced hepatic toxicity in rats. Food Chem. Toxicol. 38 (5), 411-416.

22. Seeram, N. P., Schutzki, R., Chandra, A. and Nair, M. G. 2002. Characterization, quantification, and bioactivities of anthocyanins in Cornus species. J. Agric. Chem. 50, 2519-2523.

23. Wang, J., and Mazza, G. 2002. Inhibitory effects of anthocyanins and other phenolic compounds on nitric oxide production in LPS/IFN-gamma-activated RAW 264.7 macrophages. J. Agric. Food Chem. 50(4), 850-857.

24. Gamal, H., Douaa, M. S., Salwa, A. F., and Abo, B. M. 2013. Modulation of autophagy enhances the apoptotic cell death in human T lymphoma cells treated with anthocyanin. Egypt. Acad. J. Biol. Sci. 5 (2), 87-97.

25. Zhao, C, Giusti, M. M., Malik, M., Moyer, M. P., and Magnuson, B. A. 2004. Effects of commercial anthocyanin-rich extracts on colonic cancer and non tumorigenic colonic cell growth. J. Agric. Food Chem. 52 (20), 6122-8.

26. Hyun, J. W., and Chung, H. S. 2004. Cyanidin and Malvidin from Oryza sativa cv. Heugjinjubyeo mediate cytotoxicity against human monocytic leukemia cells by arrest of $\mathrm{G}(2) / \mathrm{M}$ phase and induction of apoptosis. J. Agric. Food Chem. $52(8), 2213-2217$.

27. Meiers, S., Kemeny, M., Weyand, U., Gastpar, R., von Angerer, E., and Marko, D. 2001. The anthocyanidins cyanidin and delphinidin are potent inhibitors of the epidermal growth- factor receptor. J. Agric. Food Chem. 49, 958-962.

28. Renault, J. H., Thépenier, P., Zéches-Hanrot, M., Le Men-Olivier, L., Durand, A., Foucault, A., Margraff, R. 1997. Preparative separation of anthocyanins by gradient elution centrifugal partition chromatography. J. Chromatogr. A, 763, 345-352.

29. Cabrita, L., Andersen, Ø. M. 1999. Anthocyanins in blue berries of Vaccinium padifolium. Phytochemistry 52 (8), $1693-$ 1696. 